\title{
The effects of antisense insulin-like growth factor-I receptor oligonucleotide on human cord blood lymphocytes
}

\author{
Y Yang, J Niu and L Guo \\ Pediatrics Institute, Children's Hospital, Shanghai Medical University, 183 Feng Lin Road, Shanghai 200032, China \\ (Requests for offprints should be addressed to Y Yang; Email: yyang@shmu.edu.cn)
}

\begin{abstract}
Our objective was to study the effects of type I insulin-like growth factor receptor (IGF-IR) on human cord blood lymphocyte (CBL) functions. First, we used RT-PCR to determine the expression of IGF-IR at the mRNA level in CBL. We then inhibited the expression of IGF-IR in CBL by the antisense oligonucleotide for the IGF-IR gene. We measured the changes in interleukin (IL)-2, -4 and interferon- $\gamma$ (IFN $\gamma$ ) at mRNA levels by RT-PCR, immunoglobulin $M(\operatorname{lgM})$ production by $C B L$ with an ELISA and lymphocyte proliferation by a ${ }^{3} \mathrm{H}$-thymidine uptake technique. Our results showed that IGF-IR mRNA was detected in both non-activated and activated $\mathrm{CBL}$, but the expression levels in the activated $\mathrm{CBL}$ were higher than those in the non-activated CBL. After being exposed to the antisense oligonucleotide, a $50 \%$ reduction in the amount of IGF-IR mRNA occurred. Accordingly, the proliferation of CBL to mitogen was significantly reduced about $50 \%$, and the production of IgM from CBL was also markedly decreased. In the phytohemagglutinin-stimulated CBL culture system, when the IGF-IR antisense oligonucleotide existed, the mRNA levels of IFN $\gamma$ and IL-2 decreased $30-50 \%$ and IL-4 decreased $20-30 \%$. We concluded that IGF-IR is most likely involved in the process of CBL proliferation and production of immunoglobulin and cytokines. It might therefore play an important role in the modulation of the immune functions.
\end{abstract}

Journal of Molecular Endocrinology (2002) 28, 207-212

\section{Introduction}

Many other investigators and our previous study (Yang et al. 1999) have demonstrated that almost all components of the insulin-like growth factor (IGF) axis are expressed in immune organs (thymus and lymph nodes) and cells. Evidence also suggests that IGF affects immune functions and may be involved in immunoregulation (Gelato 1993, Marie 1993, Kooijman et al. 1996, Krishnaraj et al. 1998, Dorshkind \& Horseman 2000). Moreover, some studies have shown that IGF-I promotes cord blood $\mathrm{T}$ cell maturation ( $\mathrm{Tu}$ et al. 2000), and interferon- $\gamma$ (IFN $\gamma$ ) production and proliferation (Tu et al. 1999). The actions of IGF-I are also reported to be mediated via the IGF-I receptor (IGF-IR) (Reiss et al. 1992). However, whether IGF-IR also plays a crucial role in immune cell proliferation and function has not yet been defined. In order to study the effects of IGF-IR on human cord blood lymphocytes (CBL), we examined the expression of mRNA for IGF-IR in CBL, and investigated the regulation of antisense oligodeoxynucleotides (ODN) for the IGF-IR gene on CBL proliferation and production of immunoglobulin and cytokines.

\section{Materials and methods}

\section{CBL separation and culture}

Human cord blood specimens were obtained from normal newborn infants. Lymphocytes were separated from heparinized blood by centrifugation on Ficoll-Hypague (SABC, Shanghai, China). The cells were cultured in RPMI 1640 medium (GIBCO, Rockville, MD, USA) containing 10\% fetal calf serum (FCS; Shanghai, China) at $37^{\circ} \mathrm{C}$ in a humidified $5 \% \quad \mathrm{CO}_{2}$ atmosphere. The mitogen 
concentrations were phytohemagglutinin (PHA; $10 \mu \mathrm{g} / \mathrm{ml}$ ) (Sigma, St Louis, MO, USA) or pokeweed mitogen (PWM; $5 \mu \mathrm{g} / \mathrm{ml}$ ) (Sigma).

This study was approved by the ethics committee of the Shanghai Medical University and Hospitals.

\section{Transfection of CBL with liposomal ODNs}

The antisense ODNs (ASO) and sense ODNs (SO), synthesized by the SBS Biotechnology Co. (Beijin, China), targeting a sequence starting $2 \mathrm{bp} 5^{\prime}$ to the ATG site of IGF-IR mRNA were as follows: ASO, 5'-CGGGAGGGAGACTTG-3'; SO, 5'-AAGTCT GGCTCGGGA-3'. We transferred the ODNs into the $\mathrm{CBL}$ by the liposome-mediated method. Liposomal ODNs were prepared following the suggestion of the liposome provider (Shanghai Institute of Biochemistry, Academia Sinica, Shanghai, China). Briefly, ODNs were dissolved in distilled water and mixed with stearylamine (SA) liposome at 1:2(w/w). The mixture was left for 25-30 min at room temperature and then added to the cultured cells. The CBL were incubated with either ASO or $\mathrm{SO}$ in a final concentration of $5 \mu \mathrm{mol} / \mathrm{l}$ for $2 \mathrm{~h}$ and were then cultured in RPMI 1640 containing $15 \%$ FCS at $37^{\circ} \mathrm{C}$ in a humidified $5 \% \mathrm{CO}_{2}$ atmosphere. The appropriate mitogen was added to the culture (either PHA for $\mathrm{T}$ cells or PWM for B cells) and incubated for 3-5 days.

\section{Proliferation assays}

Lymphocyte proliferation assays were performed by a ${ }^{3} \mathrm{H}$-thymidine uptake technique. Briefly, we added $1 \mu \mathrm{Ci}{ }^{3} \mathrm{H}$-thymidine (SINR, Shanghai, China) per well to the cell culture, and incubated it for 16-18 h. The CBL were then harvested and the incorporated radioactivity was measured in a liquid scintillation counter (Beckman, Fullerton, CA, USA). Proliferation data are expressed as c.p.m.

\section{Measurement of immunoglobulin M (IgM) production by CBL}

IgM production in the supernatant of the CBL culture was quantitated by an enzyme-linked immunosorbent assay, which was carried out according to White \& Ballow (1985).

\section{RNA isolation and RT-PCR}

Total RNA was extracted from CBL by using TRIzol (GIBCO) according to the manufacturer's protocol. RNA was quantitated by measuring absorbancy at $260 \mathrm{~nm}$ in a spectrophotometer (Shimadzu UV-1601, SSI, Kyoto, Japan). Equal amounts of RNA from each sample were taken for RT-PCR.

Total RNA $(2 \mu \mathrm{g})$ was reverse transcribed to cDNA in $20 \mu \mathrm{l}$ of reaction volume. Final reaction conditions were $1 \times$ transcription buffer, $500 \mu \mathrm{M}$ each dNTP, $0.5 \mu \mathrm{g}$ random hexamer primer, $30 \mathrm{U}$ RNasin (Promega, Madison, WI, USA) and $200 \mathrm{U}$ moloney murine leukemia virus reverse transcriptase $(\mathrm{GIBCO})$. The reaction mixture was incubated at $25^{\circ} \mathrm{C}$ for $10 \mathrm{~min}, 37^{\circ} \mathrm{C}$ for $1 \mathrm{~h}$ and the transcriptase was heat inactivated at $95{ }^{\circ} \mathrm{C}$ for 5 min. cDNA was diluted 1:5 with distilled water and kept at $-20{ }^{\circ} \mathrm{C}$ until needed. PGR was performed in $50 \mu \mathrm{l}$ buffer containing $5 \mu \mathrm{l}$ cDNA, $0 \cdot 4 \mu \mathrm{M}$ specific primers (sequence showed in Table 1), $0.2 \mathrm{mM} 4 \times \mathrm{dNTP}$ and $2 \mathrm{U}$ Taq polymerase (SABC, Shanghai, China) for 30 cycles $\left(94^{\circ} \mathrm{C}\right.$ for $1 \mathrm{~min}, 50-55^{\circ} \mathrm{C}$ for $1 \mathrm{~min}$ and $72{ }^{\circ} \mathrm{C}$ for $\left.1 \mathrm{~min}\right)$ in a PTC-100 thermocycler (MJ Research, Waltham, MA, USA). $\beta$-Actin was used as quantitative control. Each $10 \mu \mathrm{l}$ PCR product was electrophoresed on $2 \%$ ethidium bromide (EB)-stained agarose gel. By using a densitometer (GDS 8000; UVP, Cambridge, UK), EB-stained gel bands were scanned and quantitated. This process was repeated at least three times.

Data are expressed as means \pm S.D. The $t$-test was used and $P<0.05$ was regarded as statistically significant.

\section{Results}

\section{Expression and regulation of the IGF-IR gene by the antisense ODNs}

Expression of mRNA for IGF-IR was detected by RT-PCR in both non-activated and activated CBL. When CBL were stimulated with PHA in vitro, IGF-IR mRNA levels increased significantly and peaked at $24 \mathrm{~h} \quad(P<0.05$ compared with the non-activated CBL). In the presence of $5 \mu \mathrm{mol} / \mathrm{l}$ antisense ODNs, IGF-IR mRNA was markedly reduced and reached the lowest level at $24 \mathrm{~h}$. Compared with the PHA-stimulated CBL culture, a $50 \%$ decrease in IGF-IR mRNA was found. The difference was statistically significant $(P<0 \cdot 05)$. Similar changes in IGF-IR mRNA transcription appeared when CBL were stimulated with PWM and inhibited by antisense ODNs. There were no 
Table 1 PCR primer sequences and product sizes

\begin{tabular}{|c|c|c|c|}
\hline & Direction & Sequence $\left(5^{\prime}-3^{\prime}\right)$ & Product (bp) \\
\hline $\begin{array}{l}\text { Name } \\
\text { IGF-IR }\end{array}$ & $\begin{array}{l}\text { Forward } \\
\text { Reverse }\end{array}$ & $\begin{array}{l}\text { CAACCACGAGGCTGAGAAGC } \\
\text { CAGCATAATCACCAACCCTC }\end{array}$ & 537 \\
\hline IL-2 & $\begin{array}{l}\text { Forward } \\
\text { Reverse }\end{array}$ & $\begin{array}{l}\text { ACAGCTACAACTGGAGCATT } \\
\text { TGCTGTCTCATCAGCATATT }\end{array}$ & 307 \\
\hline $\mathrm{IFN} \gamma$ & $\begin{array}{l}\text { Forward } \\
\text { Reverse }\end{array}$ & $\begin{array}{l}\text { TGCAGGTCATTCAGATGTAG } \\
\text { AGCCATCACTTGGATGAGTT }\end{array}$ & 306 \\
\hline IL-4 & $\begin{array}{l}\text { Forward } \\
\text { Reverse }\end{array}$ & $\begin{array}{l}\text { GCGATATCACCTTACAGGAG } \\
\text { TTGGCTTCCTTCACAGGACA }\end{array}$ & 308 \\
\hline$\beta$-actin & $\begin{array}{l}\text { Forward } \\
\text { Reverse }\end{array}$ & $\begin{array}{l}\text { GAGGCCCAGAGCAAGAGAGG } \\
\text { GGCCAGCCAGGTCCAGAC }\end{array}$ & 386 \\
\hline
\end{tabular}

significant differences in the expression of IGF-IR mRNA between the presence or the absence of sense ODNs.

\section{Effects of IGF-IR antisense ODNs on CBL proliferation}

When CBL were cultured with PHA for 3 days, the c.p.m. values of ${ }^{3} \mathrm{H}$-thymidine incorporation were $9.5 \pm 1.3 \times 10^{4}$. However, in the presence of IGF-IR antisense ODNs, the c.p.m. values were reduced to $4.7 \pm 1 \cdot 1 \times 10^{4} \quad(P<0 \cdot 05)$. The $50 \%$ decline indicated the significant inhibition of CBL proliferation by IGF-IR antisense ODNs. Similar results were shown in PWM-stimulated CBL proliferation; when cultured with IGF-IR antisense ODNs, the c.p.m. values were decreased from $7 \cdot 5 \pm 0.4 \times 10^{3}$ to $3 \cdot 4 \pm 0 \cdot 3 \times 10^{3} \quad(P<0 \cdot 05)$. The sense ODNs did not have any effect on lymphocyte proliferation.

\section{Effects of IGF-IR antisense ODNs on IgM production by CBL}

When CBL were cultured with PWM for 5 days, IgM in the culture supernatants was detected at about $29.51 \pm 0.77 \mathrm{ng} / \mathrm{ml}$. However, after CBL were incubated with IGF-IR antisense ODNs, IgM production was reduced to $27 \cdot 18 \pm 0.59 \mathrm{ng} / \mathrm{ml}$. The decline was statistically significant $(P<0 \cdot 05)$.

\section{Effects of IGF-IR antisense ODNs on the expression of cytokine mRNA}

In non-activated $\mathrm{CBL}$, expression of mRNA for interleukin (IL)-2, -4 and IFN $\gamma$ were detected at very low levels by RT-PGR while, after PHA stimulation, their mRNA showed significant enhancement at 24, 48 and $72 \mathrm{~h}$. However, when IGF-IR antisense ODNs were added to the cultures, the up-regulation of these gene expressions induced by PHA was inhibited. Compared with PHA stimulation alone, the transcription levels of mRNA for IL-2, -4 and IFN $\gamma$ declined significantly $(P<0 \cdot 05)$. There were some differences in the extent of change of specific genes, but the general pattern was similar (Fig. 1). On the contrary, the sense ODNs had no effect on cytokine synthesis in CBL.

\section{Discussion}

It has been demonstrated that IGF-IR is present in lymphocytes and that the expression is correlated with the active status of the lymphocytes (Kozak et al. 1987, Tapson et al. 1988, Geffner et al. 1992, Johnson et al. 1992, Kooijman et al. 1992, 1995a, 1995b, Nyman \& Pekonen 1993). The results were mainly obtained from adult peripheral blood lymphocytes. In this study, we examined the expression of IGF-IR in the CBL of newborn infants at the mRNA level. Compared with adult peripheral blood lymphocytes, there were more naive lymphocytes in cord blood, but their expression and regulation of IGF-IR mRNA were similar. This implies that IGF-IR is also involved in the activated process of CBL.

IGF-IR is the most important mediator in the IGF axis, and it transfers the IGF-I signals to target 
a.

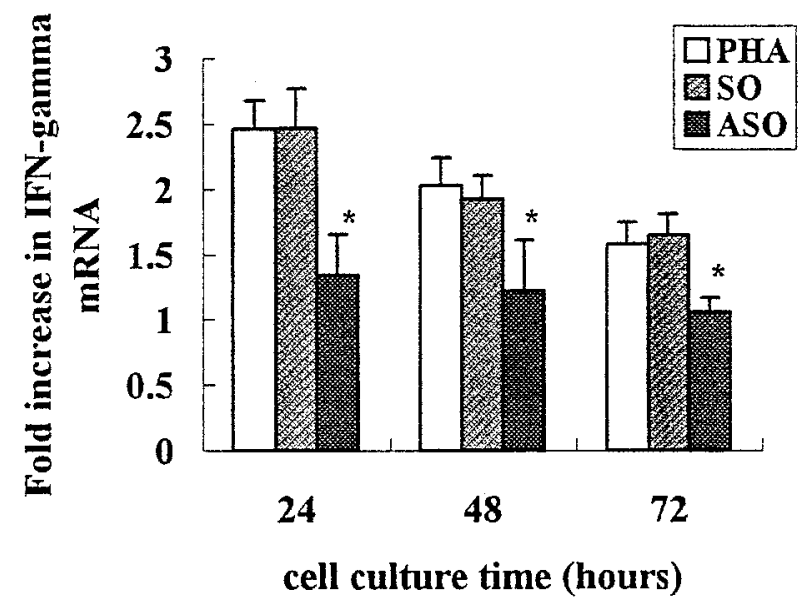

b.

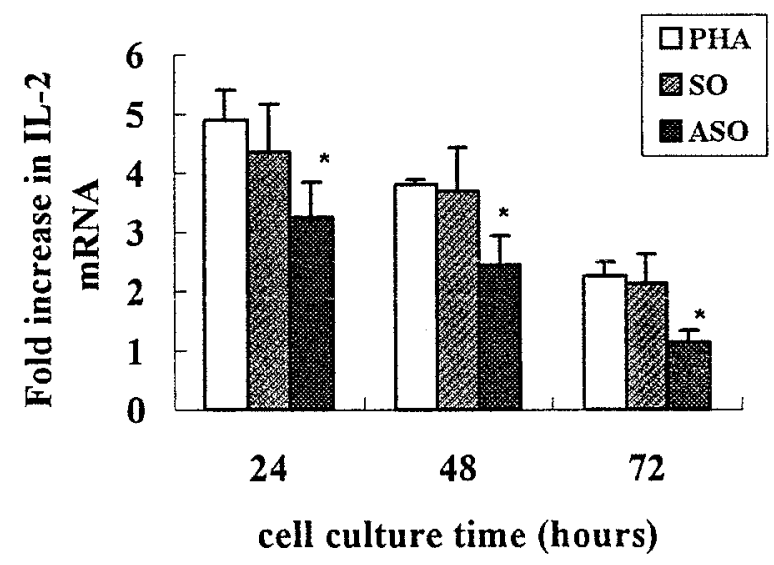

c.

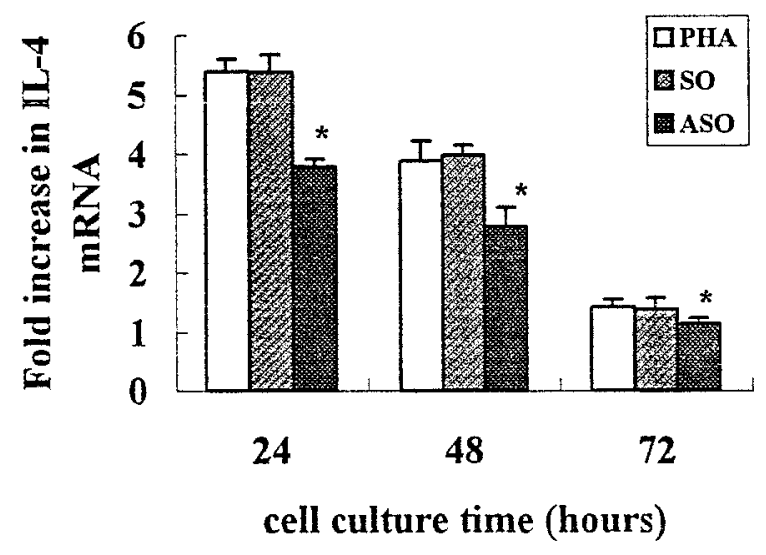

cells to promote growth and protein synthesis. In order to investigate the effects of IGF-IR on immune cells, we inhibited the expression of IGF-IR by using SA liposomes - a highly efficient reagent mediating antisense ODN transfection (Lin et al. 1995, Wang et al. 1996), and observed the changes in lymphocyte proliferation, immunoglobulin synthesis and cytokine gene expression in CBL. Although liposome has been used as an efficient transfection reagent in a wide range of eukaryotic cells, to date we have not found any reports on the application of liposomemediating gene transfection in lymphocytes. In our experiment, the ODN transfection was successful.

We found that when antisense ODNs inhibited the expressions of IGF-IR mRNA to $50 \%$, lymphocyte proliferation was reduced about $50 \%$ simultaneously, no matter whether the mitogen was PHA or PWM. Lymphocyte proliferation is the base of immune response reaction, therefore IGF-IR may participate in immune modulation in this way.

Cytokine secretion is one of the most important immune responses of $\mathrm{T}$ cells. Depending on the pattern of cytokine production, CD4+ T cells can be divided into Th1 and Th2 cells. In this study, we chose to measure IFN $\gamma$, IL-2 and IL-4, because they are produced by Th1 or Th2 cells predominantly or exclusively. In general, neonatal IL-4 production is at about $30-35 \%$ of adult level, but IFN $\gamma$ secretion is only at $8-10 \%$ of the adult amount. The Th1/Th2 balance is biased towards a Th2 response (Chipeta et al. 1998, Delespesse et al. 1998). In our study, when antisense ODNs decreased IGF-IR mRNA, the transcription of mRNA for IFN $\gamma$, IL-2 and IL-4 was significantly reduced in PHA-activated CBL. However, the amplitude of decline was different, the reductions in IFN $\gamma$ and IL-2 mRNA were more marked than

Figure 1. Time-course of cytokine mRNA expression in human cord blood lymphocytes (CBL). The cells activated by phytohemagglutinin (PHA) were incubated with or without either sense (SO) or antisense (ASO) ODNs, and were harvested at each indicated time. Expression of (a) IFN $\gamma$, (b) IL-2 and (c) IL-4 mRNA was measured by using RT-PCR as described in Materials and Methods. The mRNA levels are expressed as ratios of mRNA in stimulated cells to non-stimulated cells.

Results are shown as the means+S.E.M. of four independent experiments. ${ }^{*} P<0.05$ compared with $\mathrm{PHA}$ stimulation alone. 
IL-4 mRNA. This indicated that the expression of IGF-IR mRNA might promote the Thl immune responses in CBL, which would be beneficial to the regulation of the Th1/Th2 balance in infants.

It is known that human B cells can secrete IGF and express IGF receptors (Merimee et al. 1989, Stuart et al. 1991). Some studies have shown the regulatory effect of IGF on B cell growth and immunoglobulin production (Landreth et al. 1992, Freund et al. 1993, Kimata \& Fujimoto 1994, Kimata \& Yoshida 1994, Robbins et al. 1994). Our results showed that the antisense ODNs for IGF-IR mRNA influenced lymphocyte proliferation and immunoglobulin production in PWM-activated CBL, which demonstrated further the immune modulation of IGF-IR in B cells. The promotion of protein synthesis by IGF-I and IGF-IR may contribute to the regulation of $\mathrm{B}$ cell function.

In conclusion, it is most likely that IGF-IR is involved in the process of CBL proliferation and the production of immunoglobulin and cytokines. It may play an important role in the modulation of the immune functions.

\section{Acknowledgements}

This study was supported by a grant from the Nature Science Fund of China.

\section{References}

Chipeta J, Komada Y, Zhang XL, Deguchi T, Sugiyama K, Azuma E \& Sakurai M 1998 CD4+ and CD8+ cell cytokine profiles in neonates, older children, and adults: increasing $\mathrm{T}$ helper type 1 and $\mathrm{T}$ cytotoxic type 1 cell populations with age. Cellular Immunology 183 149-156.

Delespesse GL, Yang P, Ohshima Y, Demeure C, Shu U, Byun DG \& Sarfati M 1998 Maturation of human neonatal CD4+ and CD8+ T lymphocytes into Th1/Th2 effectors. Vaccine 16 1415-1419.

Dorshkind K \& Horseman ND 2000 The roles of prolactin, growth hormone, insulin-like growth factor-I, and thyroid hormones in lymphocyte development and function: insights from genetic models of hormone and hormone receptor deficiency. Endocrine Reviewes 21 292-312.

Freund GG, Kulas DT \& Mooney RA 1993 Insulin and IGF-1 increase mitogenesis and glucose metabolism in the multiple myeloma cell line, RPMI 8226. Fournal of Immunology 151 $1811-1820$.

Geffner ME, Bersch N \& Golde DW 1992 Insulin and IGF-I stimulate normal and virally transformed T-lymphocyte cell growth in vitro. Brain. Behavior and Immunity 6 377-386.

Gelato MC 1993 Growth hormone-insulin like growth factor I and immune function. Trends in Endocrinology and Metablism 4 106-110.
Johnson EW, Jones LA \& Kozak RW 1992 Expression and function of insulin-like growth factor receptors on anti-CD3-activated human T lymphocytes. Fournal of Immunology 148 63-71.

Kimata H \& Fujimoto M 1994 Growth hormone and insulin-like growth factor I induce immunoglobulin (Ig) E and IgG4 production by human B cell. Fournal of Experimental Medicine $\mathbf{1 8 0}$ 727-732.

Kimata H \& Yoshida A 1994 Effect of growth hormone and insulin-like growth factor-I on immunoglobulin production by and growth of human B cells. Fournal of Clinical Endocrinology and Metabolism 78 635-641.

Kooijman RK, Willems M, De Haas CJ, Rijkers GT, Schuurmans AL, Van Buul Offers SC, Heijnen CJ \& Zegers BJ 1992 Expression of type I insulin-like growth factor receptors on human peripheral blood mononuclear cells. Endocrinology 131 2244-2250.

Kooijman RK, Scholtens LE, Rijkers GT \& Zegers BJ 1995 a Differential expression of type I insulin-like growth factor receptors in different stages of human $\mathrm{T}$ cells. European fournal of Immunology 25 931-935.

Kooijman RK, Scholtens LE, Rijkers GT \& Zegers BJ 1995b Type I insulin-like growth factor receptor expression in different developmental stages of human thymocytes. Fournal of Endocrinology 147 203-209.

Kooijman RE, Hooghe Peters EL \& Hooghe R 1996 Prolactin, growth hormone, insulin-like growth factor-I in the immune system. Advances in Immunology 63 377-454.

Kozak RW, Haskell JF, Greenstein LA, Rechler MM, Waldmann TA \& Nissley SP 1987 Type I and II insulin-like growth factor receptors on human phytohemagglutinin-activated T lymphocytes. Cellular Immunology 109 318-331.

Krishnaraj R, Zaks A \& Unterman T 1998 Relationship between plasma IGF-I levels, in vitro correlates of immunity, and human senescence. Clinical Immunology and Immunopathology 88 264-270.

Landreth KS, Narayanan R \& Dorshkind K 1992 Insulin-like growth factor-I regulates pro-B cell differentiation. Blood $\mathbf{8 0}$ 1207-1212.

Lin QS, Yang JP \& Wang D 1995 SA liposomes: a highly efficient reagent mediating nucleic acid-transfection. In Biopolymers and Bioproducts: Structure, Function and Application. 11th FAOBMB Symposium, pp 46-50. Eds Organizing Committee. Samakkhisan: (dokya) Public Co. Ltd.

Merimee TJ, Grant MB, Broder CM \& Cavalli-Sforza LL 1989 Insulin-like growth factor secretion by human B-lymphocytes: a comparison of cells from normal and pygmy subjects. Fournal of Clinical Endocrinology and Metabolism 9 978-984.

Nyman T \& Pekonen F 1993 The expression of insulin-like growth factors and their binding proteins in normal human lymphocytes. Acta Endocrinologica 128 168-172.

Reiss K, Porcu P \& Sell C 1992 The insulin-like growth factor I receptor is required for the proliferation of hemopoietic cells. Oncogene 7 2243-2248.

Robbins K, McCabe S, Scheiner T, Strasser J, Clark R \& Jardieu P 1994 Immunological effects of insulin-like growth factor-I enhancement of immunoglobulin synthesis. Clinical and Experimental Immunology 95 337-342.

Stuart CA, Meehan RT, Neale LS, Cintron NM \& Furlanetto RW 1991 Insulin-like growth factor-I binds selectively to human peripheral blood monocytes and B-lymphocytes. Fournal of Clinical Endocrinology and Metabolism 72 1117-1122.

Tapson VF, Boni Schnetzler M, Pilch PF, Center DM \& Berman JS 1988 Structural and functional characterization of the human T lymphocyte receptor for insulin-like growth factor I in vitro. Fournal of Clinical Investigation 82 950-957.

Tu W, Cheung PT \& Lau YL 1999 Insulin-like growth factor 1 increases IFN- $\gamma$ and IL-6 mRNA expression and protein 
production in neonatal mononuclear cells. Pediatric Research 46 748-754.

Tu W, Cheung PT \& Lau YL 2000 Insulin-like growth factor 1 promotes cord blood $\mathrm{T}$ cell maturation and inhibits itsspontaneous and phytohemagglutinin-induced apoptosis through different mechanisms. Fournal of Immunology 165 1331-1336.

Wang D, Jing NH \& Lin QS 1996 Stearylamine liposome as a new efficient reagent for DNA transfection of eukaryotic cells. Biochemical and Biophysical Research Communications 226 450-455.

White WB \& Ballow M 1985 Modulation of suppressor-cell activity by cimetidine in patient with common variable hypogammaglobulinemia. New England Fournal of Medicine 312 198-202.

Yang Y, Guo LZ, Ma L and Liu XY 1999 Expression of growth hormone and insulin-like growth factor in the immune system of children. Hormone and Metabolic Research 31 380-384.

Received 6 December 2001

Accepted 5 March 2002 